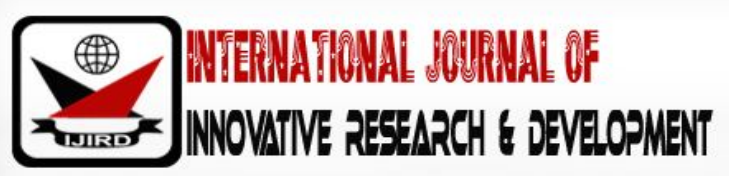

ISSN 2278 - 0211 (Online)

\section{System Quality Impact toward Continuous Intention of Using Tax E-Filing System}

\author{
Radhi Abu Bakar \\ Ph.D. Student, Universiti Utara Malaysia, Malaysia \\ Dr. Mustakim Melan \\ Senior Lecturer, Universiti Utara Malaysia, Malaysia
}

\begin{abstract}
:
Governments at all levels have launched electronic government (e-government) projects aimed at providing electronic information and services to citizens and businesses. Compared to other online service delivered by government, online tax filing is one of the most developed and widely used services and tax authorities tend to be at the leading edge of IT application. In Malaysia, e-Filing which was introduced in year 2006 by the Inland Revenue Board of Malaysia is receiving much attention and there has been an upward trend in the adoption of the system among taxpayers every year. Even though tax e-filing system have improved, issues regarding system quality such as technical difficulties, system breakdown and downtimes issues which forced the users to queue in the system still exist. The purpose of this study is to investigate the relationship between system quality and individual taxpayers' continuous intention toward using e-filing system in Malaysia. This study adopts the DeLone \& McLean Information System Success Model as a theoretical basis firstly because it is a wellestablished theory and is widely used in information system technical-related research. This review will include quantitative techniques and focused on individual taxpayer in Malaysia. The quantitative data that gained from the questionnaire are analysed by using the Smart PLS3. The methods of data analysis are selected based on the research questions and the variable characteristics.
\end{abstract}

Keywords: E-filing, system quality, individual taxpayer, is success model, continuous intention

\section{Introduction}

Governments around the world are increasing the use of information and communication technologies by enhancing electronic government (e-government) to improve the delivery of public services and the dissemination of public administration information to the public. E-government has become increasingly important to the aims at better and effective governance together with the significant benefits including the radically shrinking communications and information costs, improving connectivity, maximizing speed, broadening to reach, eradicating distance and encouraging participation of public in government (Irani, Eliman and Jackson, 2007). E-government defined as "use of information and communication technologies (ICTs) and internet to enhance the access and delivery of all facets of government services and operations for the benefits of citizens, business, employees and other stakeholders" [Srivastava and Teo, 2007). Thus, e-government uses technology to support a government's interaction with multiple stakeholders; citizens, employees, business and other government agencies (Joseph, 2013). The success of e-government depends on the importance that citizen's place on factors such as convenience and usefulness of such services. Considering importance of e-government services for the development of the country, government around the world and including Malaysia have been spending large amount of money in the form of hardware, software, training, maintenance and communication infrastructure for the development of e-government services (Abdullah, Mansor and Hamzah, 2013). Although great efforts have been taken by Malaysian government in the development of e-government services, the adoption rate of this e-services among citizens is still low (Thominathan and Ramayah, 2013) compared with the availability of e-government services. More importantly, most of the government agencies that provides online public services faces challenges to retain and keeping citizens engage to continued use the existing e-government services (Teo, Srivastava and Jiang, 2008). According to Bhattacherjee (2001), even initial acceptance of information system (IS) is an essential first stage to realize an IS success but its eventual achievement or success highly depends on continued use than first time use.

One prominent type of e-government is the introduction of the e-filing system for income tax. Compared to other online service delivered by government, online tax filing is one of the most developed and widely used services. In the public sector 
with the move of online service, tax authorities tend to be at the leading edge of IT application (Connolly and Bannister, 2008). Through this system, taxpayers are able to submit their tax returns electronically to the tax authorities.

In Malaysia, electronic tax filing (e-filing) system is one of project under e-government flagship in Multimedia Super Corridor (MSC) (Hussein et al., 2011). Although e-filing system receiving much attention, growing trends and serves measurable benefits to the tax payers and tax authorities (Ramoo et al., 2013), this system has been slow in gaining acceptance among taxpayers (Azmi, Kamarulzaman and Hamid, 2012) and quite low compared to the total number of registered tax payers and expectation of Inland Revenue Board Malaysia (IRBM) in Malaysia (Ghazali, 2014) despite huge investment, improvement of technology and various promotion activities to enhance or increase level of usage e-filing system (Aziz and Idris, 2012). Thus, understanding factors that influences continuance intention towards e-government services is an essential step to achieve government goal (Alalwan, 2013) particularly to achieve government goal in e-filing context, to reduce more operation and management cost (Thominathan and Ramayah, 2014) and to ensure success of this services (Hu, Brown, Thong, Chan and Tam, 2009). This is because continuance at individual level have been deems to be important for long term sustainable of web-based services (Lee and Kwon, 2011) and central to the survival for the electronic service providers (Bhattacherjee, 2001).

Moreover, even though tax e-filing system have improved, gained significant response and existed many years in most of the countries including in Malaysia, issues regarding system quality such as technical difficulties, system breakdown and downtimes issues which forced the users to queue in the system still exist and this caused user dissatisfied and weaken overall users' perception towards the system (Chen et al., 2015).

\section{The DeLone \& McLean (D \& M) IS Success Model}

The exploration of IS (Information System) continuous intention has been shaped significantly by DeLone and McLean's (1992) IS Success Model. The model introduced six major variables of information system continuous intention; System Quality, Information Quality, Information System Use, User satisfaction, Individual Impact, and Organizational Impact. In the D \& M IS Success model "System Quality" measures technical success, "Information Quality" measures semantic success and "Use, User satisfaction, Individual Impact and Organizational Impact" measures effectiveness success.

In 2003, DeLone \& McLean extended their model and added service quality as an important indicator of success measure. Instead of adding more success measures, DeLone and McLean (2003) combined the different impact measures and categorized them as a net benefit in their extended model. The model includes six success dimensions, and holds that the constructs of information quality, system quality, and service quality individually and jointly affect the factors of use and user satisfaction. The model further states that there is a reverse relation between the amount of system use and user satisfaction. User satisfaction and use jointly affect net benefit.

This study only focused on system quality and how it relates with the continuous intention to use e-filing. System quality is defined as the degree in which the functionalities of the system can best address customer needs, with as much ease and as minimal problems encountered as possible (Chang et al., 2005; DeLone and McLean, 2003). Examples of such functionalities include user interface consistency, ease of use, response rates, and program management, can best address customer needs (Chang et al., 2005; DeLone and McLean, 2003; Wang, 2008; Wang and Liao, 2008). System quality in an ecommerce context, as with traditional IS, is reflected by usability, availability, reliability, adaptability and fast response time of the system (DeLone and McLean, 2003). Continuous intention is one's intention to continue using or long term usage intention of a technology (Bhattacherjee, 2001). In this study, seven (7) items were selected to measure system quality in areas that covered usability, availability, functionality and navigation as the main characteristics of system quality.

\section{Methodology}

The unit of analysis chosen for this study is the individual taxpayers in Malaysia who have used the e-filing system to file their tax online at least once. Based upon IRBM's Annual Report (2016), there are 2,922,229 million individual taxpayer's population throughout Malaysia who have used the e-filing system in year 2015. Sekaran (2003) suggests that for a population of over 1 million, a sample size of 384 is acceptable. The present study targets sample of 2,000 respondents, approximately 143 taxpayers from each branch of the 14 states' capital city of Malaysia. The Malaysian e-filing service http:/ / ez.hasil.gov.my is considered an application area for this study.

The research process designed to achieve the aims and answer the questions was conducted in quantitative method using structured, closed item surveys. Simple random sampling (Sekaran, 2000) will be used in this research study. Simple random sample is chosen from a larger set of a population. A simple random sample is a subset of a statistical population in which each member of the subset has an equal probability of being chosen. A simple random sample is meant to be an unbiased representation of a group.

Data analysis for this quantitative phase of the research was done using the SEM approach. PLS path modelling becomes more appropriate for real world applications and more advantageous to use when models are complex (Fornell and Bookstein, 1982). The soft modelling assumptions of PLS technique (i.e., ability to flexibly develop and validate complex models) gives it the advantage of estimating large complex models (Akter, D’Ambra and Ray, 2011). Measurement model was used to explain or assess constructs' reliability and validity of the current study. Secondly, structural model was used to conduct bivariate correlation analysis and simultaneous regressions analyses to establish correlations, and relationship effects 
among constructs under investigation. Additionally, using the PLS mechanisms of algorism and bootstrapping to examine the moderating effects. Partial least squares (PLS) is now well-known as the alternative to SEM method - this includes AMOS, LISREL, and other programs (Hair et al., 2010).

\section{Finding}

The purpose of this study is to investigate the relationships among latent variables; therefore, the latent analysis technique was the suitable option. Total of 406 surveys were complete and returned and additionally decidedly usable giving a reasonably worthy rate. In this way, the example scope of 406 for the review was remain adequate to execute different measurable assessments and give dependable yield with arrangement (Hair et al., 2006).

Table 1 summaries the characteristics of the 406 respondents in the sample from e-filing user samples of individual taxpayers in Malaysia. In total, from the 406 respondents, the respondents are 183 male respondents ( 45.07 percent) and 223 females (54.93 percent). The majority numbers of respondents were in an age group of 30-39 totalling 170 (41.87 percent). The lowest numbers of respondents were in an age group of 60 or above totalling 9 (2.22 percent). In a response to the question about how frequent one uses the internet, 95.07 percent of the respondents chose the option of everyday.

\begin{tabular}{|c|c|c|}
\hline \multicolumn{3}{|c|}{ Profiles of E-filing User Samples } \\
\hline Respondent Characteristics & Responses & Percent \\
\hline Gender: & & \\
\hline Male & 183 & 45.07 \\
\hline Female & 223 & 54.93 \\
\hline Total & 406 & 100.00 \\
\hline Age: & 106 & 26.11 \\
\hline 29 years and below & 170 & 41.87 \\
\hline 30 - 39 years & 93 & 22.91 \\
\hline $40-49$ years & 28 & 6.89 \\
\hline 50 - 59 years & 9 & 2.22 \\
\hline 60 years and above & 406 & 100.00 \\
\hline Total & & \\
\hline Frequent Use of Internet: & 386 & 95.07 \\
\hline Everyday & 13 & 3.20 \\
\hline 3 times a week & 5 & 1.23 \\
\hline Once a week & 1 & 0.25 \\
\hline Twice a month & 1 & 0.25 \\
\hline Once a month & 406 & 100.00 \\
\hline Total & & \\
\hline
\end{tabular}

Table 1: Profiles of Respondent Characteristics

This examination embraced internal consistency reliability. This sort of unwavering quality is utilized to survey a scale whereby a few things are summed to frame an aggregate mark to be develop (Hair et al., 2006). Subsequently, the interior reliability unwavering quality was legitimate correlation information of this review in the survey questionnaire. The Survey questionnaire are in the pattern of a Likert scale.

To guarantee that the instrument created delivered exactly and precisely regarding estimations, Cronbach's coefficient alpha was chosen as a proper factual test for evaluating the dependability and legitimacy of the survey questionnaire. These results are reported in Table 2.

\begin{tabular}{|c|c|c|c|c|c|}
\hline $\begin{array}{c}\text { Measurement } \\
\text { Item }\end{array}$ & Item & $\begin{array}{c}\text { Cronbach' } \\
\text { s Alpha }\end{array}$ & rho_A & $\begin{array}{c}\text { Composi } \\
\text { te } \\
\text { Reliabilit } \\
\mathbf{y}\end{array}$ & (AVE) \\
\hline System Quality & 7 & 0.855 & 0.881 & 0.888 & 0.534 \\
\hline
\end{tabular}

Table 2: Cronbach's Alphas, Rho A, Composite Reliability and Average Variance Extracted (AVE) in the Main Survey

Discriminant validity evaluation has turned into a for the most part acknowledged essential for investigating connections between dormant factors. For difference based auxiliary condition demonstrating, for example, halfway slightest 
squares, the Fornell-Larcker paradigm and the examination of cross-loadings are the predominant methodologies for assessing discriminant legitimacy.

By method for a re-enactment contemplate, we demonstrate that these methodologies don't dependably recognize the absence of discriminant legitimacy in like manner research circumstances. Therefore researcher propose an alternative approach, based on the multitrait-multimethod matrix, to assess discriminant validity: the Heterotrait-Monotrait ratio of correlations. These results are reported in Table 3.

\begin{tabular}{|c|c|c|}
\hline & $\begin{array}{c}\text { Continuous Intention To } \\
\text { Use }\end{array}$ & $\begin{array}{c}\text { System } \\
\text { Quality }\end{array}$ \\
\hline $\begin{array}{c}\text { Continuous Intention To } \\
\text { Use }\end{array}$ & 1.000 & \\
\hline System Quality & 0.836 & 1.000 \\
\hline
\end{tabular}

Table 3: Discriminant Validity: Heterotrait-Monotrait Ratio

As illustrated in Figure 1, System Quality (SQ) as a latent construct was measured by seven items comprising of SQ1 to SQ7. In addition, the endogenous variable is the continuous intention to use (CITU) e-filing. This was measured in five items (indicators).

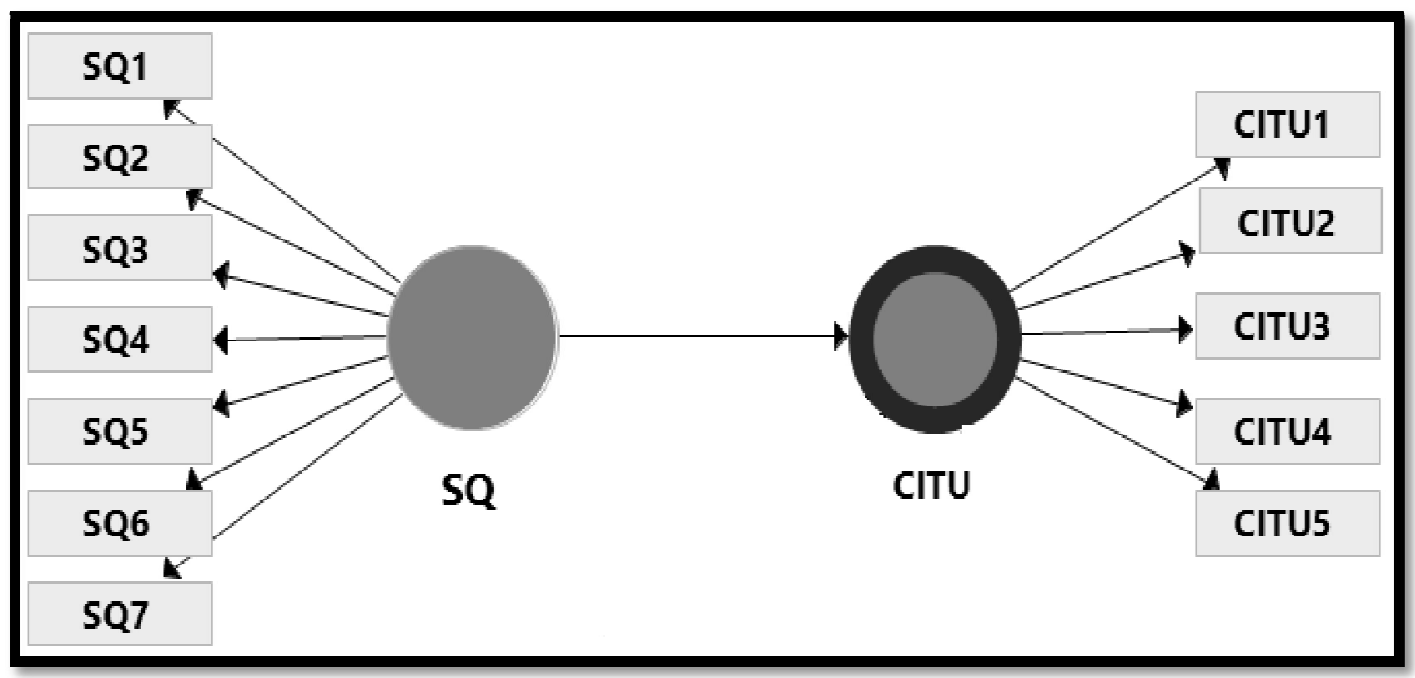

Figure 1: The Establishment of the Constructs

\begin{tabular}{|c|c|c|c|c|c|}
\hline Construct & Item & Loading & T Value & R Square & R Square Adjusted \\
\hline System Quality & SQ1 & 0.761 & 21.806 & 0.673 & \\
\cline { 2 - 4 } (SQ) & SQ2 & 0.687 & 18.125 & & \\
\cline { 2 - 4 } & SQ3 & 0.650 & 14.214 & & \\
\cline { 2 - 4 } & SQ4 & 0.871 & 78.847 & & \\
\cline { 2 - 4 } & SQ5 & 0.681 & 14.370 & & \\
\cline { 2 - 4 } & SQ6 & 0.771 & 29.246 & & \\
\cline { 2 - 4 } & SQ7 & 0.668 & 17.691 & & \\
\hline
\end{tabular}

Table 4: The Establishment of the Constructs

Once the goodness of the outer model has been confirmed (Table 4), the next stage was to test the hypothesized relationships among the variables. By running PLS Algorithm (Figure 2) and bootstrapping (Figure 3) using SmartPLS, the hypothesized model was tested. 


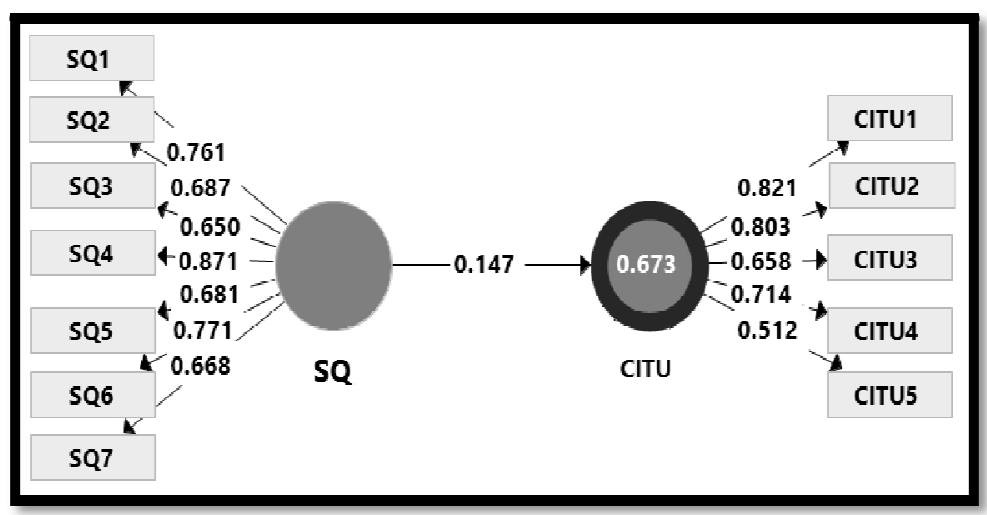

Figure 2: Path Model Result

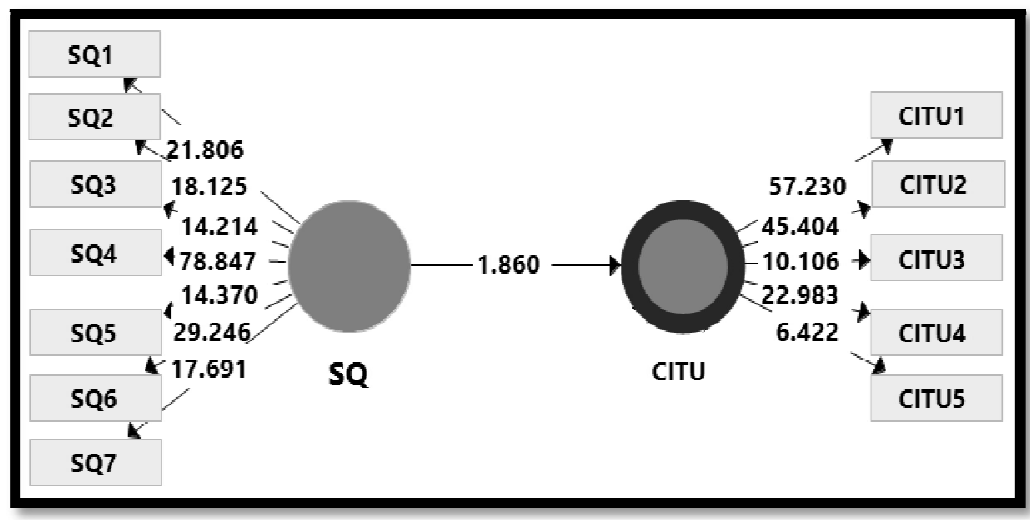

Figure 3: Path Model Significance Result

For the purpose of concluding whether the path coefficients are statistically significant or not, bootstrapping techniques embedded in this study with SmartPLS 3. As reported in Table 5, the T-Values with each path coefficient were generated using bootstrapping technique and P-Values subsequently were generated.

\begin{tabular}{|c|c|c|c|c|c|}
\hline Hypothesis & Relationship & Std. Beta & $\begin{array}{c}\text { Std. Deviation } \\
\text { (STDEV) }\end{array}$ & T Statistics & Decision \\
\hline H & SQ -> CITU & 0.147 & 0.079 & 1.860 & Supported \\
\hline
\end{tabular}

Table 5: Bootstrapping Result: Hypothesis Testing

The results showed that System Quality (SQ) has significant effect on the continuous intention to use e-filing system ( $\beta=$ $0.147, t^{*}=1.860, p<0.05$ ). Therefore, the hypothesis of the effect of System Quality (SQ) on continuous intention to use e-filing system was supported. From the PLS model, it has been exactly and hypothetically found that the best miserly model was accomplished with no changes (Kline, 2005). The basic model was in this way acknowledged as the final model.

The finding proposed that system quality shows critical components that impact continuous intention to use e-filing system. What's more, it was found that system quality variables were imperative elements influencing to e-filing system adoption at a critical level of 0.05 .

In this study, the aftereffects of hypotheses testing research address as real discoveries are presented. In this section, the research questions below can be answered by testing hypotheses.

\subsection{Research Question}

What is the relationship between System Quality and continuous intention toward using e-filing system?

\subsection{Hypotheses}

There is a positive relationship between System Quality and continuous intention toward using e-filing system.

\section{Theory and Practices Implications}

This study identifies an important determinant of system quality impact toward continuous intention of using tax efiling system. From the results it was found that system's usability and availability, functionality and navigation facility show critical components that impact continuous intention to use e-filing system. The implication of the results indicates that easy 
navigation facility is highly related to determining system quality. Items that are related to navigation facility of the web site and accessibility are important to determine citizens' perceived system quality. That implies that when citizens are filing their tax return and other tax-related activities they prefer that the web site should have proper and easy navigation facilities and easy information access. According to Chen (2010), system quality is the important characteristic of online tax web sites. To retain the current users, the tax authority needs to simplify the interface design to make the system easier to use. They should try to maintain easy design and functionality of the web site where citizens can get fast access to the information, get anywhere on the web site very easily and find the necessary information. They need to provide a well-organized web site that will help citizens to complete their tax related task with a minimal effort.

Along with the theoretical contributions, there are some practical implications of the research findings. It is important for the practitioner such as IRBM and other government organizations that are involved with the delivery of e-services, to be aware of the factors that contribute towards the future maintenance of the quality of the e-government services. The results can help IRBM to identify the key quality criteria for the e-filing web site that are valued by citizens, thus can improve its service delivery process. Additionally, IRBM can use the results to retain the current users and, along with that, they can use them to create new users. Both of these are important in making the service successful.

\section{Limitations and extensions}

Significance of any examination is to understand its impediments (Delon, Ruyter and Lemmink, 2004). This study makes a commitment to the level of advancement appropriation writing, however despite the fact that this review has given pertinent and intriguing bits of knowledge into the continuous intention of using tax e-filing system, it is vital to perceive its restrictions. There are a few constraints that should be recognized. Information technology has changed quickly.

The first limitation of the current study is that it was not possible to collect individual online taxpayers' addresses from the tax authorities. Because of personal confidentiality concerns, the tax authority was unwilling to provide the addresses of online taxpayers. Walk-in taxpayers that were dealing at the IRBM's service counter at all branches within Malaysia who were experienced with the e-filing system were selected as a sample for the data collection. The external validity of the research results thus may be limited to Malaysia.

Another limitation lies in the fact that the items used to measure system quality were selected from different studies. These constructs were measured directly with items, and dimensions were not included in this study. In the empirical analysis, trace of multidimensionality was not found within the items treated in the model. However, there can be additional items used to measure the variables, and it is proposed that further research may be conducted including additional items to judge the dimensionality as well as possible extension of the model even further.

Within the present study, system quality criteria was proposed in the context of tax e-filing services, and tested in Malaysia. Further testing is proposed to test the applicability of the quality criteria in different geographical locations and within their respective tax e-filing or similar comparable services.

\section{Conclusion}

This research explored an important area of e-government particularly in the online tax system. It focused on the Malaysian online tax system and evaluated Malaysian tax information-related web sites to find out the impact of system quality criteria on the continuous intention of using such web sites. A citizen survey was conducted to identify the impact of system quality criteria from a user's perspective. Results indicate that system's usability and availability, functionality and navigation facility were found to have an impact on the continuous intention of using government e-services.

\section{References}

i. Abdullah, N. R. W., Mansor, N. B. and Hamzah, A. (2013) Keeping ahead of the game: Innovations and challenges in egovernment in Malaysia. The Economic and Labour Relations Review, 24(4), 549-567.

ii. Akter, S., D'Ambra, J. and Ray, P. (2011) An Evaluation of PLS based Complex Models: The Roles of Power Analysis, Predictive Relevance and GoF Index. In: Proceedings of the Seventeenth Americas Conference on Information Systems, Detroit, Michigan, August 4th -7th 2011.

iii. Alalwan, J. A. (2013) Continuance Intention to Use Government 2.0 Services: The Impact of Citizens' Satisfaction and Involvement. International Journal of Electronic Government Research, 9(3), 58-73.

iv. Aziz, S. A. and Idris, K. M. (2012) The Determinants of Tax E-filing among Tax Preparers in Malaysia. World Journal of Social Sciences, 2(3), 182-188.

v. Azmi, A. A. C., Kamarulzaman, Y. and Hamid, N. H. A. (2012) Perceived Risk and the Adoption of Tax E-Filing. World Applied Sciences Journal, 20(4), 532-539.

vi. Bhattacherjee, A. (2001) Understanding Information Systems Continuance: An Expectation-Confirmation Model. MIS Quarterly, 25(3), 351-370.

vii. Chang, I. C., Li, Y. C., Hung, W. F. and Hwang, H. G. (2005) An empirical study on the impact of quality antecedents on tax payers acceptance of internet tax-filing systems. Government Information Quarterly, 22, 389-410.

viii. Chen, C. (2010) Impact of quality antecedents on taxpayer satisfaction with online tax-filing systems - an empirical study. Information \& Management, 47(5-6), 308-15. 
ix. Chen, J. V., Jubilado, R. J. M., Capistrano, E. P. S. and Yen, D. C. (2015) Factors affecting online tax filing-An application of the IS Success Model and trust theory. Computers in Human Behavior, 43(C), 251-262.

x. Connolly, R. and Bannister, F. (2008) eTax Filing \& Service Quality: The Case of the Revenue Online Service. Proceedings of World Academy of Science, Engineering and Technology, International Journal of Social, Behavioral, Educational, Economic, Business and Industrial Engineering, 2(2).

xi. Delon, W. V., Ruyter, K. D. and Lemmink, J. (2004) An empirical assessment of the influence of customer emotions and contact employee performance on encounter and relationship satisfaction. Journal of Business Research, 57(4), 437-44.

xii. DeLone , W. H. and McLean, E. R. (2003) The DeLone \& McLean Model of information system success: A Ten-Year Update. Journal of Management Information System, 19(4), 9-30.

xiii. Fornell, C. and Bookstein, F. (1982) A comparative analysis of two structural equation models: LISREL and PLS applied to market data. In: C. Fornell (ed.). A second generation of multivariate analysis. New York, NY: Praeger, 289-323.

xiv. Ghazali, N. (2014) The Adoption Factors of Using e-Government Services (Study Case in Malaysia). In: 2nd International Conference on Technology, Informatics, Management, Engineering \& Environment Bandung, Indonesia, 326-330.

xv. Hair, J., Black, W. C., Babin, B. J. and Anderson, R. E. (2010) Multivariate Data Analysis. 7th ed., Upper Saddle River, New Jersey: Pearson Education International.

xvi. Hair, J., Black, W. C., Babin, B. J. and Anderson, R. E. and Tatham, R. (2006) Multivariate Data Analysis. 6th ed., Upper Saddle River, New Jersey: Prentice-Hall.

xvii. Hu, P. J.-H., Brown, S. A., Thong, J. Y. L., Chan, F. K. Y.and Tam, K. Y. (2009) Determinants of service quality and continuance intention of online services: The case of eTax. Journal of the American Society for Information Science and Technology, 60(2), 292-306.

xviii. Hussein, R., Mohamed, N., Ahlan, A. R. and Mahmud, M. (2011) E-government application: an integrated model on G2C adoption of online tax. Transforming Government: People, Process and Policy, 5(3), 225-248.

xix. Inland Revenue Board Malaysia (IRBM) (2016). Annual Report 2015. Available from: http:/ / www.hasil.gov.my/ pdf/pdfam/ laporan_tahunan_2015.pdf.

xx. Irani, Z., Eliman, T. and Jackson, P. (2007) Electronic transformation of government in the UK: A research agenda. European Journal of Information Systems, 16(4), 327-335.

xxi. Joseph, R. C. (2013) A structured analysis of e-government studies: Trends and opportunities. Government Information Quarterly, 30(4), 435-440.

xxii. Kline, R. B. (2005) Principles and Practice of Structural Equation Modeling. 2nd ed., New York: The Guilford Press.

xxiii. Lee, Y. and Kwon, O. (2011) Intimacy, familiarity and continuance intention: An extended expectation -confirmation model in web-based services. Electronic Commerce Research and Applications, 10(3), 342-357.

xxiv. Ramoo, V., Ramayah, T., Lo, M.-C. and Ping, T. A. (2013). Electronic Tax Filing: Preliminary Evidence from a Developing Country. In: Pablos, Patricia Ordóñez De Lovelle, Juan Manuel Cueva Gayo, Jose Emilio Labra Tennyson, Robert D. (eds). E-Procurement Management for Succefull Electronic Government Systems. United States: IGI Global, 147-156.

xxv. Sekaran, U. (2000), Research Method for Business: A Skill-Building Approach, John Wiley and Sons, Inc.

xxvi. Sekaran, U. (2003), Research Methods for Business: A Skill-Building Approach, 4th ed., New York: John Wiley \& Sons, Inc.

xxvii. Srivastava, S. C. and Teo, T. S. H. (2007) E-Government Payoffs: Evidence from Cross-Country Data. Journal of Global Information Management, 15(4), 20-40.

xxviii. Teo, T. S. H., Srivastava, S. C. and Jiang, L. (2008) Trust and Electronic Government Success: An Empirical Study. Journal of Management Information Systems, 25(3), 99-131.

xxix. Thominathan, S. and Ramayah, T. (2013) Towards Understanding the Intention to Use and Continuance Usage Intention of E-Filing System in Malaysia: The Moderating Role of Perceived Risk. In: Tarnay K. et al. (eds). Research and Development in E-Business through Service-Oriented Solutions. United States: IGI Global, 307-324.

xxx. Thominathan, S. and Ramayah, T. (2014). Explaining the e-Government Usage Using Expectation Confirmation Model: The Case of Electronic Tax Filing in Malaysia. In L. G. Anthopoulos \& C. G. Reddick (eds.), L. G. Anthopoulos and C. G. Reddick (eds.). Government E-Strategic Planning and Management, Public Administration and Information Technology, 3. New York, NY: Springer New York, 287-304.

xxxi. Wang, Y. S. (2008) Assessing e-commerce systems success: A respecification and validation of the DeLone and McLean model IS success. Information Systems Journal, 18(5), 529-557.

xxxii. Wang, Y. S. and Liao, Y. W. (2008) Assessing e-government systems success: A validation of the DeLone and McLean model of information system success. Government Information Quarterly, 25(4), 717-733. 